RIIT Vol.X. Núm.3. 2009 269-283, ISSN 2594-0732, FI-UNAM

(artículo arbitrado)

DOI: http://dx.doi.org/10.22201/fi.25940732e.2009.10n3.025

\title{
A Flat Solar Collector Built from Galvanized Steel Plate, Working by Thermosyphonic Flow, Optimized for Mexican Conditions
}

\section{Un colector solar plano construido de lámina de acero galvanizada, operando por flujo termosifónico, optimizado para las condiciones mexicanas}

\author{
Á. Marroquín de Jesús \\ Centro de Investigación en Ciencia Aplicada y Tecnología Avanzada \\ Instituto Politécnico,Nacional, Unidad Querétaro.
E-mail: amarroquind@utsj.edu.mx, a_marroquin2003@yahoo.com.mx \\ J.M. Olivares-Ramírez \\ Centro de Investigación en Ciencia Aplicada y Tecnología Avanzada \\ Instituto Politéenico Nacional, Unidad Querétaro. \\ E-mail:jmolivaresr@utsjr.edu.mx \\ G.A. Ramos-López \\ Centro de Investigación en Ciencia Aplicada y Tecnología Avanzada \\ Instituto Politéenico Nacional, Unidad Querétaro. \\ E-mail:gramos@ipn.mx \\ R.C. Pless \\ Centro de Investigación en Ciencia Aplicada y Tecnología Avanzada \\ Instituto Politécnico Nacional, Unidad Querétaro. \\ E-mail:rpless@ipn.mx
}

(Recibido: mayo de 2008; aceptado: octubre de 2008)

\begin{abstract}
Design, construction, and testing of the thermal performance of a flat solar collector for domestic water heating are described. The absorbing plate is built from readily available materials: two sheets of galvanized steel, one of the channelled type, the other one flat, which are joined by electric welding. The absorber is connected to a 198-L thermotank, insulated with polyurethane foam. In terms of receiving surface, the prototype tested here has an area of $1.35 \mathrm{~m}^{2}$, about $20 \%$ smaller than comparable copper-tube-based collectors offered in the market. Temperature measurements conducted over a 30-day period gave values which were a few degrees lower than the theoretically calculated water temperatures. Momentary thermal efficiency values between $35 \%$ and $77 \%$ were observed. The water temperature achieved in the tank at the end of the day averages $65^{\circ} \mathrm{C}$ in winter weather conditions in the central Mexican highland. This design of solar water heater is well suited to Mexican conditions, as it makes use of the high local intensity of the solar radiation, and as the channel shape of the ducts minimizes bursting during the rare occurrences of freezing temperatures in the region; it also has the advantage of being manufacturable at low cost from simple materials.
\end{abstract}

Keywords: Flat solar collectors; thermosyphonic flow; channelled plate; simulation;instantaneousthermalefficiencies. 
DOI: http://dx.doi.org/10.22201/fi.25940732e.2009.10n3.025

A Flat Solar Collector Built from Galvanized Steel Plate, Working by Thermosyphonic Flow, Optimized for Mexican Conditions

\begin{abstract}
Resumen
Se describe el diseño, construcción y pruebas del desempeño térmico de un colector solar plano para calentamiento de agua para uso doméstico. La placa absorbedora se construyó de materiales fácilmente asequibles: dos placas de acero galvanizado, una del tipo acanalado y la otra plana, unidas mediante soldadura de arco eléctrico. La placa absorbedora está conectada a un termotanque con capacidad de 198 L, aislado con espuma de poliuretano. La superficie receptora de este prototipo es de $1.35 \mathrm{~m}^{2}$, aproximadamente $20 \%$ más pequeña comparado con los colectores, basados en tubos de cobre, ofertados en el mercado. Mediciones de temperatura por un periodo de 30 dias, arrojaron valores menores por algunos grados que las temperaturas de agua teóricamente calculadas. Se observaron valores momentáneos de eficiencia térmica entre $35 \%$ y $77 \%$. La temperatura del agua lograda al final del dia promediaba en $65^{\circ} \mathrm{C}$ en condiciones de invierno, en el altiplano central mexicano. Este diseño de calentador solar de agua está bien adaptado a las condiciones mexicanas, por aprovechar la alta intensidad local de la radiación solar, y porque la forma acanalada de los ductos minimiza rupturas durante las escasas ocurrencias de temperaturas de congelamiento en esta región; además es fácilmente manufacturable, a bajo costo, partiendo de materiales simples.
\end{abstract}

Desciptores: Colectores solares planos, flujo termosifónico, lámina acanalada, simulación, eficiencias térmicas instantáneas.

\section{Introduction}

World interest in renewable energies is driven by three main considerations. The first is our awareness that the reserves of hydrocarbon and nuclear prime materials are finite and that they are concentrated in only a few regions of our planet. The second is our experience, in many parts of the world, of irreversible local ecological damage following the unbridled use of fossil resources. The third, and possibly most important, consideration is the potential for dramatic global climate change due to the greenhouse effect of the carbon dioxide which is emitted during combustion of hydrocarbon fuels. These considerations have, in recent years, driven a substantial and growing research effort to harness alternative sources of energy, with a view to at least partially replacing hydrocarbons and nuclear prime materials as our energy base. In part, this research has been directed at developing basic technologies of fundamental importance and of general applicability on a planet-wide scale; in part, the studies have been directed at applying and optimizing basically established technologies to the climatic, economic, and social peculiarities of specific regions of our planet. The present is a study of this latter kind.

Despite the undoubted benefits offered by solar energy, and the enormous potential it has for application in tropical and subtropical countries, like Mexico, this energy source is, as yet, hardly used in these regions.
Not even as uncomplicated an application as solar domestic-water-heating has made significant inroads in this part of the world. The prime reason for this is likely the relatively high initial acquisition cost of solar water heaters, which in Mexico are 6 to 12 times as expensive as the customary water boilers operated with liquid-propane gas.

The Mexican context makes a cogent argument for the development and large-scale installation of small, single-residence solar water heaters, based on the following considerations:

1) Due to the tropical and subtropical geographic location of the country, solar angles are high throughout the year. The lowest noontime solar altitude is $34^{\circ}$, for winter solstice in the extreme Northwest corner of the country.

2) By far the largest part of the population lives in the central highland of the country, at altitudes of $1500 \mathrm{~m}$ and above, which makes for a particularly high solar intensity.

3) Outside of the rainy season (June through October), the country generally enjoys cloudless skies, which provides good solar conditions during the colder part of the year, when hot bath water is required. During the moderately rainy summer, temperatures are usually high enough to provide lukewarm water directly from the cold-water tank located on the roof top. 
DOI: http://dx.doi.org/10.22201/fi.25940732e.2009.10n3.025

Á. Marroquín de Jesús, J.M. Olivares-Ramírez, G.A. Ramos-López and R.C. Pless

4) Winds are usually very light, reducing convective heat loss.

5) Air temperatures are moderate, reducing conductive energy losses.

6) Feed water temperatures are moderate, thus reducing the required energy input.

7) A large proportion of the Mexican population live in areas where the chance to experience freezing temperatures is remote, so that special adaptations to prevent tube bursting can be dispensed with, which permits a more economical design.

8) While Mexico at present still counts among the petroleum-exporting countries, the outlook is for depletion of the main oil-producing fields within a decade and an ensuing period of rapidly increasing net oil imports, in a setting of rising hydrocarbon prices due to worldwide petroleum demand. This argues for development of alternative energy sources.

9) Mexico belongs to the large countries of the world, with over 100 million inhabitants, who constitute a significant internal market.

10) A large proportion of the population belongs to the middle class and lower middle class, with sufficient economic means to make the modest investment required for a simple solar collector system.

11) Middle class and lower middle class mostly live in small single-family houses, rather than apartment complexes, and this trend is strengthening. These residences generally have an underused small flat roof top, which can, in addition to the cold-water tank and a gas tank, accommodate a small flat solar collector, along with its thermal tank.

Three decades ago, 30\% of the Israeli population was already using solar domestic-water systems with thermosyphonic flow (Shitzer et al., 1979). For large and important parts of Mexico, where cloudless winter weather prevails, this technology is even more appropriate than for the Israeli case, where the Mediterranean climate makes for cool and rainy winters.

The present report describes the design and construction of a simple flat solar collector for producing hot bath water for a one-family residence, tailored to the special climatic, economic and social conditions of Mexico, with an emphasis on simplicity, robustness, and low production cost. The prototype was tested, during the various seasons of the year, in real working conditions in San Juan del Río, a city with high average levels of solar radiation throughout the year, located in the state of Querétaro in the central part of Mexico. We ascertained that the water temperature obtained with this collector is sufficiently high for domestic use, and we determined experimentally the thermal efficiency of the collector under thermosyphonic operating conditions and calculated the effect of different tilt angles of the absorbing plate on the thermal efficiency of the absorber.

\section{Mathematical model}

For an initial evaluation of the possible thermal characteristics of a simple flat solar collector in the local conditions we used the averaged solar radiation values reported across the entire year by Almanza (2003) for the city of Querétaro, close to San Juan del Río and with a similar climate. For February, the month in which most of our experiments were performed, it gives a value of $494.5 \mathrm{~W} / \mathrm{m}^{2}$ for the total radiation, averaged over the daylight hours. The map published by Almanza shows similar values throughout the Mexican territory, so that the results obtained in our present work should be valid, as an approximation, for the entire country. We used the set of equations given by Holman (2001), which are based on a consideration of shape factors and take account of various heat transfer processes such as radiation, convection, and conduction:

$$
\begin{aligned}
& \left.\frac{\dot{q}}{A}\right|_{S}=h_{3}\left(T_{2}-T_{3}\right)+\varepsilon_{2}\left(E_{b 2}-E_{b 3}\right) \\
& 9.9 E_{b 2}-9 E_{b 1}-0.9_{b 3}+\left.(9) \frac{\dot{q}}{A}\right|_{R a d} \\
& =h_{3}\left(T_{\alpha}-T_{2}\right)+(10)\left(\frac{k_{1,2}}{\Delta x_{1,2}}\right)\left(T_{1}-T_{2}\right) \\
& \frac{\dot{q}}{A} \mid=\frac{T_{1}-T_{5}}{\Delta x} \cdot \frac{1}{k_{e}}+\frac{1}{h}
\end{aligned}
$$

The various symbols used in these equations are defined in the Nomenclature. Figure 1 shows the three systems considered in the analysis: System 1 is the absorbing panel formed from the channeled galvanized sheet and the flat galvanized sheet, System 2 is the glass cover of the collector, and System 3 is the 
surrounding air. It is assumed that there is no heat loss from inside the absorbing panel. For the temperature value inside the absorbing panel one assumes that there is no circulation of the water. For the water temperature, it is necessary to take into account the thermal conductivity for water, $h$.

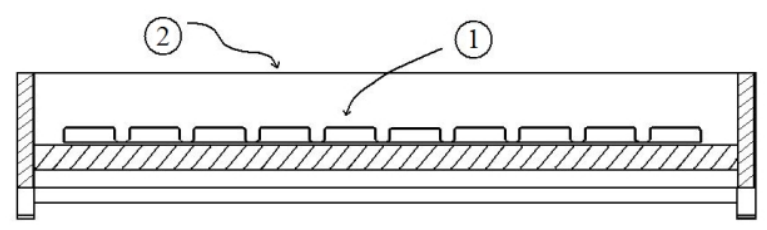

Figure 1. The three systems considered in the evaluation of the channeled-sheet flat solar collector

The particular values for the various parameters used in our evaluation were: $494.5 \mathrm{~W} / \mathrm{m}^{2}$ for the radiation density, $20 \mathrm{~W} / \mathrm{m}^{2}{ }^{\circ} \mathrm{C}$ for the thermal convectivity constant for ambient air, $h_{3} ; 14^{\circ} \mathrm{C}$ for the ambient air temperature, $T_{3}$ or $T_{\alpha} ; 0.90$ for the emissivity of the cover glass, $\varepsilon_{2} ; 384.6 \mathrm{~W} / \mathrm{m}^{2}$ for the emissive power of the ambient air, $E_{b 3}$, calculated from the Stefan-Boltzmann constant and $T_{3} ; 0.030 \mathrm{~W} / \mathrm{m}{ }^{\circ} \mathrm{C}$ for the thermal conductivity constant for the air in the chamber, $k_{1,2} ; 0.20 \mathrm{~m}$ for the distance from the absorbing surface to the glass cover, $\Delta x_{1,2} ; 60.9 \mathrm{~W} / \mathrm{m}^{\circ} \mathrm{C}$ for the thermal conductivity constant for the channeled sheet, $k_{e} ; 1.0 \mathrm{~mm}$ for the thickness of the channeled sheet, $\Delta \mathrm{x}$; $10 \mathrm{~W} / \mathrm{m}^{2}{ }^{\circ} \mathrm{C}$ for the thermal convectivity constant for water, $h$. Solving equations 1,2 , and 3 by the iterative method given by Holman (2001) we obtain the temperature values listed in table 1.

Table 1: Calculated temperature values for the different systems

\begin{tabular}{cccc}
\hline System & Variable & $\mathrm{T}(\mathrm{K})$ & $\mathrm{T}\left({ }^{\circ} \mathrm{C}\right)$ \\
\hline Glass Cover & $T_{2}$ & 312.0 & 38.8 \\
Channeled & $T_{1}$ & 371.5 & 98.3 \\
Sheet & & & \\
Water & $T_{5}$ & 333.6 & 60.4 \\
\hline
\end{tabular}

These theoretically obtained values were promising in the sense that they predicted a water temperature which was sufficiently high for the normal household uses. Based on these results we decided to build the prototype shown in figure 2.

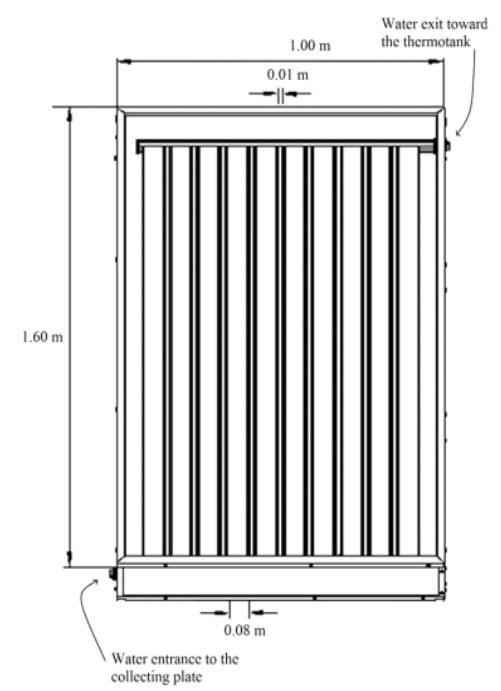

a)

Figure 2. Views of the prototype flat solar collector: a) Front view of the absorbing plate, and $b$ ) side view of the complete system 
DOI: http://dx.doi.org/10.22201/fi.25940732e.2009.10n3.025

Á. Marroquín de Jesús, J.M. Olivares-Ramírez, G.A. Ramos-López and R.C. Pless

\section{Description of the prototype}

The absorbing surface is made of commercial 20-gauge galvanized channeled steel sheet, which is joined to a 20 -gauge flat galvanized steel sheet, both sheets being finished in flat black color on their outer surfaces. The sheets are joined at the side edges by electric welding. The upper and lower edges of the absorber finish in headers made of galvanized steel tubing $0.0381 \mathrm{~m}$ in diameter, each with a $1-\mathrm{cm}$ wide longitudinal slit into which the absorbing panel is slid and then fixed by electric welding. These headers finish in external threads by which they are joined to the 0.0127-m inner diameter tubes, which feed cold water to the lower header and from the upper header carry away hot water to the thermotank. The whole collector system is configured as a Z-type array, because of the inherent advantages of this type over the U-type (Wang and $\mathrm{Wu}, 1990)$. To resist the pressure which builds up inside the absorbing panel, the two sheets are welded together at several internal positions, using a coated electrode. The inner dimensions of the channels are: $0.08 \mathrm{~m}$ wide, $0.010 \mathrm{~m}$ high, and $1.50 \mathrm{~m}$ long; as the absorbing plate contains ten such channels, the total inner volume of the panel is 12 liters. The absorbing panel constructed in this manner is placed inside a box built on a framework made of $3 / 4$-inch rectangular tubular profile. Each of the four lateral faces of the box is formed from two 22-gauge galvanized steel sheets, $0.018 \mathrm{~m}$ apart, with the intervening space filled with Styrofoam panels. The bottom face of the box is made of a single 22-gauge galvanized steel sheet, which is covered on the inside with an $0.050 \mathrm{~m}$ thick layer of Styrofoam insulation, on which the absorbing plate rests directly. The cover is a single sheet of window glass of $0.0040 \mathrm{~m}$ thickness, supported and attached to the box by means of 0.010-m aluminum angle and sealed with a silicone band, which helps to adjust for the thermal expansion of the glass. Systems which are similar in some respects have been described (Dunn and Tweed, 1981; Clark, 1984), but their performance was not reported.

In the present work, this collector was used in a fixed position, with a tilt angle of $20^{\circ}$ from the horizontal, facing due south. The thermotank consists of an inner cylinder $0.60 \mathrm{~m}$ in diameter and $0.70 \mathrm{~m}$ long, made of 18-gauge flat galvanized steel sheet, and an outer cylinder $0.80 \mathrm{~m}$ in diameter and $0.90 \mathrm{~m}$ long, of 20 -gauge sheet. The space between inner and outer cylinder was filled with injectable polyurethane. The thermotank holds 198 liters; its outer surface is painted skyblue. The thermotank was positioned so that the top header of the collector was $25 \mathrm{~cm}$ below the cold leg fitting on the storage tank, to prevent backflow during the night hours (Rudnick et al., 1986).

\section{Measurement methods}

Direct solar radiation was measured immediately next to the solar collector using a NIP pyrheliometer mounted on a Solar Tracker ST-1, both from Eppley Laboratories, U.S.A. Total global radiation incident on an horizontal surface was measured piranometrically using a Davis Vantage Pro2 Plus weather station. The water temperature in the thermotank was generally measured in the topmost water layer of the tank with a bimetal thermometer with $0.305 \mathrm{~m}$ stem length, reading in the range from $-10^{\circ} \mathrm{C}$ to $110^{\circ} \mathrm{C}$, and recorded on a HandyLog ${ }^{\circledR}$ from ITP Software Ltd, USA. This unit has a DB- $525^{\circledR}$ data collector and an RS-232 port to link to the computer, and it allows different measurement programs to be set up. The information was processed with the DB-Lab ${ }^{\circledR}$ software from ITP Software Ltd. The water temperature in different locations inside the collector was recorded with thermocouples measuring in the $10^{\circ} \mathrm{C}$ to $110^{\circ} \mathrm{C}$ range. The water temperature distribution inside the thermotank was evaluated using a thermocouple affixed to a sliding probe inserted through a small opening in the top of the tank. Surface temperatures were measured with an infrared Class IIIa thermometer, model 08406, from Cole Parmer, USA, which had been calibrated, for the surface of interest, by measurement compared to a thermocouple. Infrared thermal photography was performed using a Thermacam PM695 from Flir systems, USA. Microscopy was performed with an Olympus PME111B/312B instrument. Water flow was measured with a Blue-White ${ }^{\circledR}$ fluxmeter, capable of measuring in the range from 0.4 to 4 liters/minute, installed in a vertical stretch between the hot-water exit from the collecting panel and the entry to the thermotank. The tests were conducted in the city of San Juan del Río (in the state of Querétaro, Mexico), located at $20^{\circ} 23^{\prime} \mathrm{N}, 99^{\circ} 59^{\prime} \mathrm{W}$. The local climate is of the semidry, temperate type.

\section{Experimental results}

\section{General performance tests}

During 30 consecutive days, from February 1 to March 3,2006 , the water temperature in the thermotank was monitored continuously during daylight hours. Maximum water temperature during the day and water 
DOI: http://dx.doi.org/10.22201/fi.25940732e.2009.10n3.025

A Flat Solar Collector Built from Galvanized Steel Plate, Working by Thermosyphonic Flow, Optimized for Mexican Conditions

temperature at sunrise on the following morning were also recorded. Figure 3 shows the temperatures on the outer surface of the glass cover, the surrounding air temperature, measured in the shade, and the temperature of the water as it enters and as it exits the collector, for the daylight hours of February 6, 2006. The average values for these temperatures are $38^{\circ} \mathrm{C}, 25^{\circ} \mathrm{C}$, $34^{\circ} \mathrm{C}$, and $47^{\circ} \mathrm{C}$, respectively. The values were measured over 12 hours, in conditions of clear sky, low incidence of clouds, and light breeze. The highest temperature of the water exiting the collector, $66^{\circ} \mathrm{C}$, was measured at 2:40 PM.

During the hours of high insolation, the temperature differential between water entering and water exiting the collector was generally between $13^{\circ} \mathrm{C}$ and $19^{\circ} \mathrm{C}$, comparable to the values $\left(10^{\circ} \mathrm{C}\right.$ to $\left.18^{\circ} \mathrm{C}\right)$ reported by Shitzer et al. (1979) for thermosyphonic domestic water heaters operating at the height of Israeli summer, and distinctly better than the value of $11^{\circ} \mathrm{C}$ referred to by Grossman et al. (1977) for a thermosyphonically operated parallel-plate collector tested in South Africa. Similar temperature profiles were observed on most other days during the month of February 2006.

On that same day, February 6, surface temperatures on the absorbing plate were measured, using the infrared thermometer. Along each channel, seven points, numbered 1 through 7, were marked at equal intervals, from the lower end of the plate to the upper end, and the channels themselves were numbered as 1 to 10 , from the left (the side of water entry) to the right. For each point, the temperature was measured at hourly intervals. Temperatures averaged over the seven points for each channel are shown, in dependence of time, in figure 4.

This figure shows a maximum temperature of $66^{\circ} \mathrm{C}$ for all ten channels at about 14:30 PM. All channels show a similar temperature progression through time, which indicates that the collecting plate contributes across its entire width about equally to the heating of the water.

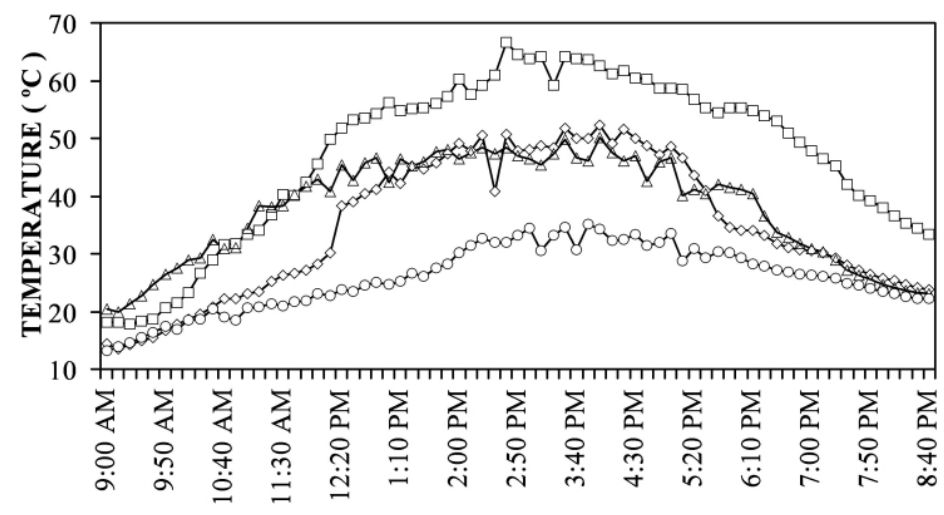

Water entering the collector $\prec$ Water exiting the collector $-\square-$ Outside surface of the glass cover $-\leftarrow$ Ambient air $-\infty$

LOCAL TIME

Figure 3. Temperatures measured for the collector during February 6, 2006. Local solar noon occurred at 12:35 PM.

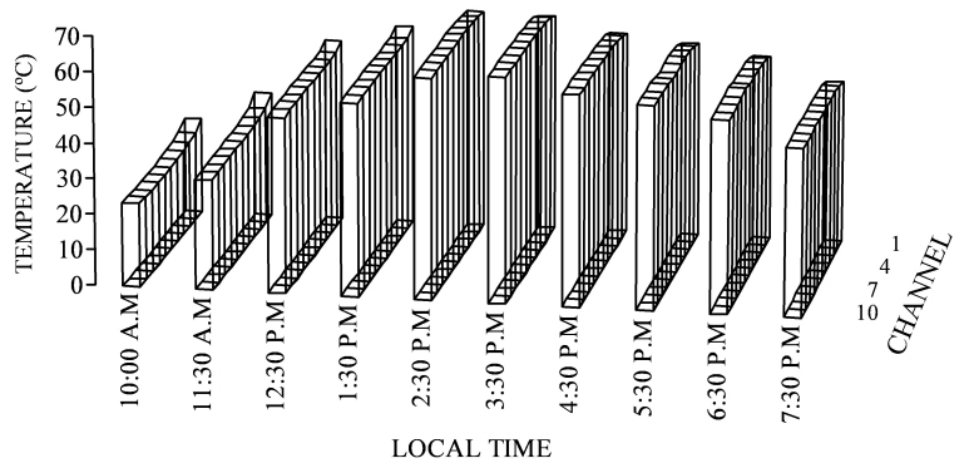

Figure 4. Average surface temperature values for each channel, shown over time for February 6, 2006 
DOI: http://dx.doi.org/10.22201/fi.25940732e.2009.10n3.025

Á. Marroquín de Jesús, J.M. Olivares-Ramírez, G.A. Ramos-López and R.C. Pless

To indicate the typical outer surface temperature distribution along a given channel, figure 5 shows the temperature values for seven points each, in the leftmost and in the rightmost channel of the collecting panel, as well as in the central channel, all at 14:30 PM on February 6, 2006.

The points were selected equidistant along the channel, and numbered from the bottom up. For each channel the temperature difference between point 1 and point 7 is about 9 degrees. The highest temperatures are found equally in channels 1, 6, and 10, at the highest position on each channel. In general, the warmer zones are found in the upper part of the channels, as expected. Each channel shows a monotonous, though not exactly linear temperature profile.

This contrasts with the highly linear temperature distributions reported, for different hours of the day by Shitzer et al. (1979) for the central riser pipe of their collector, though in their case the temperatures referred to the water inside the pipe, while our present experiment deals with the outside surface temperature of the metallic channels.

The metal surface temperature of $66^{\circ} \mathrm{C}$ measured in this experiment at the highest measurement points along channels 1, 6 and 10 is just slightly higher than the temperature of $62^{\circ} \mathrm{C}$ measured for the exiting water at the same point in time (Figure 3 for a time of 14:30 PM), which evidences the good thermal contact between metallic channel and the flowing water which is achieved with the present simple design. In contrast, with plate-and-tube-arrays, Shitzer et al. (1979) have observed differences of $20^{\circ} \mathrm{C}$ and more between the surface temperature at the centerline of the plate between

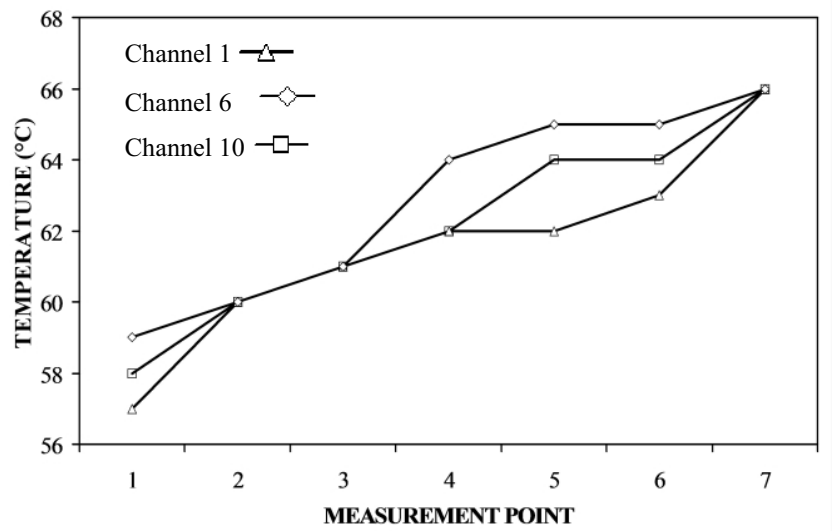

Figure 5. Surface temperature distribution over the seven points of measurement along channels 1,6 , and 10, taken at 14:30 PM. adjacent tubes and the water temperature inside the tubes, which they ascribed to poor thermal bonds between plate and tube.

For a more general test of the surface temperature distribution on the collecting plate, infrared photography was used. Figure 6 shows an even temperature gradient as one moves upward on the collector, with a maximal surface temperature of $64.0^{\circ} \mathrm{C}$ on the center part of the upper header. The even temperature distribution from left to right across the collector is also noteworthy.

Figure 7 summarizes, for February 2006, the temperatures of the uppermost water layer inside the thermotank, taken daily at 7:00 AM and 19:00 PM, as well as the decrease in temperature which occurred nightly between 19:00 PM and 7:00 AM on the following morning. Each day at 20:00 PM, 60 liters of water were taken from the tank.

On February 19, at 20:00 PM, 150 liters of water at $70^{\circ} \mathrm{C}$ were removed, whereupon on February 20 at 7:00 AM the water temperature in the thermotank was $35^{\circ} \mathrm{C}$. On that day, the maximal temperature reached in the thermotank was $55^{\circ} \mathrm{C}$, i.e. the water temperature increased by $20^{\circ} \mathrm{C}$ in less than one day.

Water temperature distributions obtained inside the thermotank under thermosyphonic flow conditions were determined by direct measurement. The temperature profiles shown in figure 8 attest to a continuous increase in tank water temperature throughout the hours of insolation. The layering of temperatures in the tank, a precondition for efficient use of the hot water, is also evident.

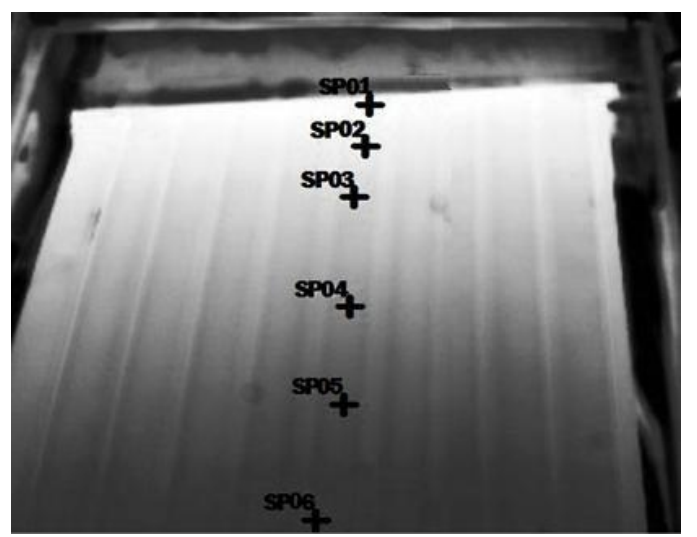

Figure 6. Surface temperatures by infrared photograph. For the spots marked on the image, the temperatures given by the system were as follows: SP01: $64.0^{\circ} \mathrm{C}, S P 02: 61.5^{\circ} \mathrm{C}$, SP03: $59.5^{\circ} \mathrm{C}, S P 04: 57.1^{\circ} \mathrm{C}, S P 05: 55.2^{\circ} \mathrm{C}, S P 06: 53.2^{\circ} \mathrm{C}$ 
DOI: http://dx.doi.org/10.22201/fi.25940732e.2009.10n3.025

A Flat Solar Collector Built from Galvanized Steel Plate, Working by Thermosyphonic Flow, Optimized for Mexican Conditions

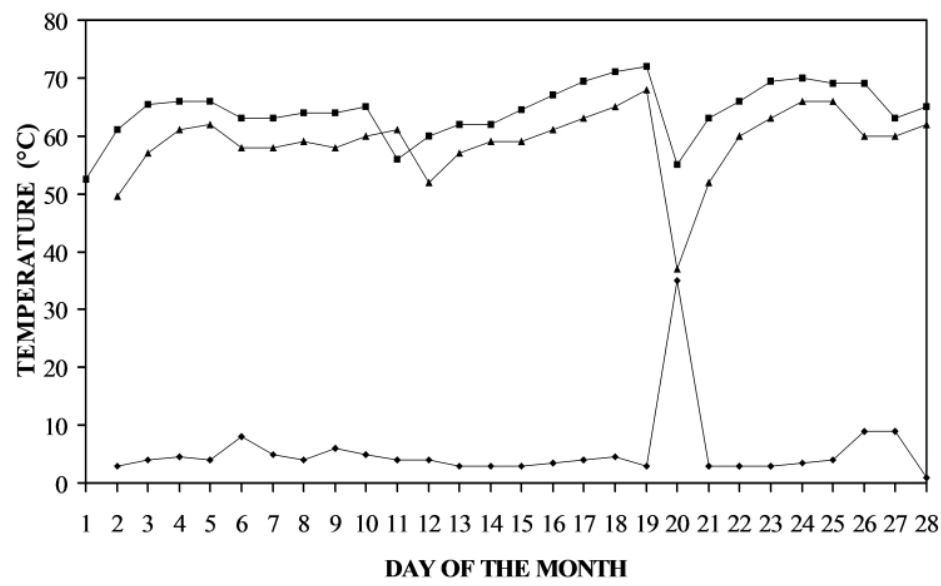

Temperature at 7:00 $\mathrm{AM} \leftarrow$

Temperature at 19:00 PM $\rightarrow$

Overnight temperature drop $\rightarrow$

Figure 7. Evening and morning water temperatures in the thermotank, for February 2006

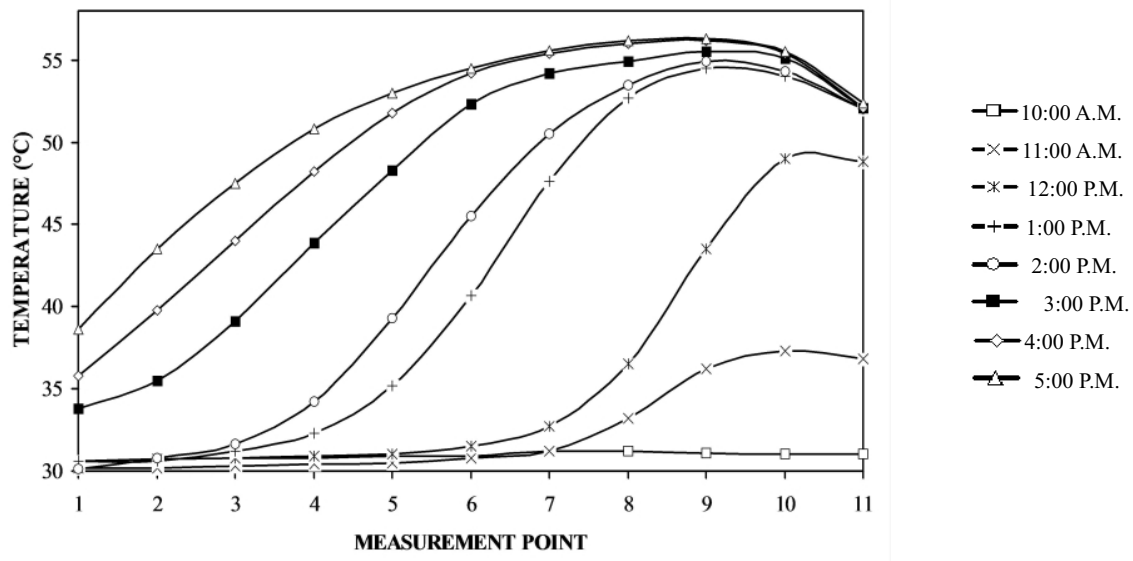

Figure 8. Temperature profiles observed inside the thermotank at different times, under thermosyphonic operation, without hot-water usage

The measurement points were spread $5 \mathrm{~cm}$ apart along the vertical center line of the tank. Point 1 is $4 \mathrm{~cm}$ off the inner bottom surface. Point 9 is the highest point still in contact with the water.

\section{Flow measurement}

Figure 9 shows the water flow through the absorbing plate and the thermotank, throughout the afternoon hours of May 10, 2006, a day of changing weather conditions. The flow becomes significant as soon as the temperature of the water exiting the collector is around $52^{\circ} \mathrm{C}$. The figure shows for this test a maximum flow of 78 liters/hour, which was maintained for 1 hour, followed by another hour of slightly lesser flow. In these 2 hours, a water volume equivalent to about two-thirds of the tank flows through the collecting panel. At these high flow rates, Reynolds numbers around 2300 can be calculated for the flow through the 0.0127-m diameter exit tube $\left(\right.$ at $\left.60^{\circ} \mathrm{C}\right)$, so that the overall flow performance will under these conditions be limited by turbulent flow in this section. Obviously, in the body of the collector with its ample cross section, linear flow is much slower, with much lower Reynolds numbers (below 30 , at $60^{\circ} \mathrm{C}$ ) and laminar flow conditions will prevail. The flow rates observed by us (up to $48 \mathrm{~L} / \mathrm{m}^{2} \mathrm{~h}$ ) are 
high for a system operating on the thermosyphonic principle, compared to the values (up to $20 \mathrm{~L} / \mathrm{m}^{2} \mathrm{~h}$ ) reported by Shitzer et al. (1979) and by Rudnick et al. (1986) for thermosyphonic domestic hot-water systems in Israel. This is not surprising, as these latter systems in general used an array of relatively narrow risers in the collector, instead of the wide channels which characterize the present prototype. It is doubtful whether even higher flow rates would be desirable, as they might significantly perturb the thermal gradient established in the thermotank (Shitzer et al., 1979), which would negatively affect the thermal efficiency of the system.

\section{Thermal efficiency}

To gain insight into the approximate thermal efficiency of our solar collector under typical operating conditions, we calculated instantaneous efficiencies according to the formalism given by Tiwari (2002a), whose equation $3.43 \mathrm{~b}$ reads:

$$
\eta_{i}=\frac{\dot{Q_{u}}}{A_{c} l_{(t)}}=\frac{\dot{q_{a b}}}{I_{(t)}}-\frac{U_{L}\left(T_{p}-T_{a}\right)}{I_{(t)}}=\tau_{0} \alpha_{0}-U_{L} \frac{T_{p}-T_{a}}{I_{(t)}} .
$$

Here, $\mathrm{I}(\mathrm{t})$ is the instantaneous irradiance on the collector plate, and $T_{p}$ and $T_{a}$ are the collector surface temperature and ambient air temperature, respectively. The simple equation given above was considered sufficient for our purpose of obtaining rough estimates for the thermal efficiency that could be expected. Thus, we did not use more complicated equations that contain higher-power terms of the $\left(T_{p}-T_{a}\right)$ difference (e.g. Fischer et al., 2004), as the prevailing conditions in central Mexico entail very low wind speeds. Also, we disregarded the possible incidence-angle dependence of the zero-loss efficiency, as we were interested mainly in the thermal efficiency during the hours around noon, when the direction of incident radiation is reasonably close to normal relative to the receiving surface, and it is known that the loss of solar absorptance of flat black surfaces is minimal for incidence angles of up to $50^{\circ}$ relative to the normal (Duffie and Beckman, 1991).

The overall heat loss coefficient which appears in the above equation, $U_{L}$, was evaluated according to the procedure given in Tiwari (2002b), taking into account the dimensions and the materials used in the construction of our prototype, for the following typical conditions: $T_{p}-T_{a}=30^{\circ} \mathrm{C}$; glass cover temperature $=45^{\circ} \mathrm{C}$; wind speed $=2 \mathrm{~m} / \mathrm{sec}$; time of day, 13:40 local time (solar noon): latitude $=20^{\circ} \mathrm{N}$ (San Juan del Río); date: November 4; orientation of collector plate: due South. The transmittance-absorptance product $\tau_{0} \alpha_{0}$ was taken as 0.84 , according to Tiwari (2002c). Using these parameters, instantaneous efficiencies $\eta_{\mathrm{i}}$ were calculated for different tilt angles running from $5^{\circ}$ to $60^{\circ}$ and for different radiation intensities running from $500 \mathrm{~W} / \mathrm{m}^{2}$ through $1000 \mathrm{~W} / \mathrm{m}^{2}$. For simplicity, these latter values

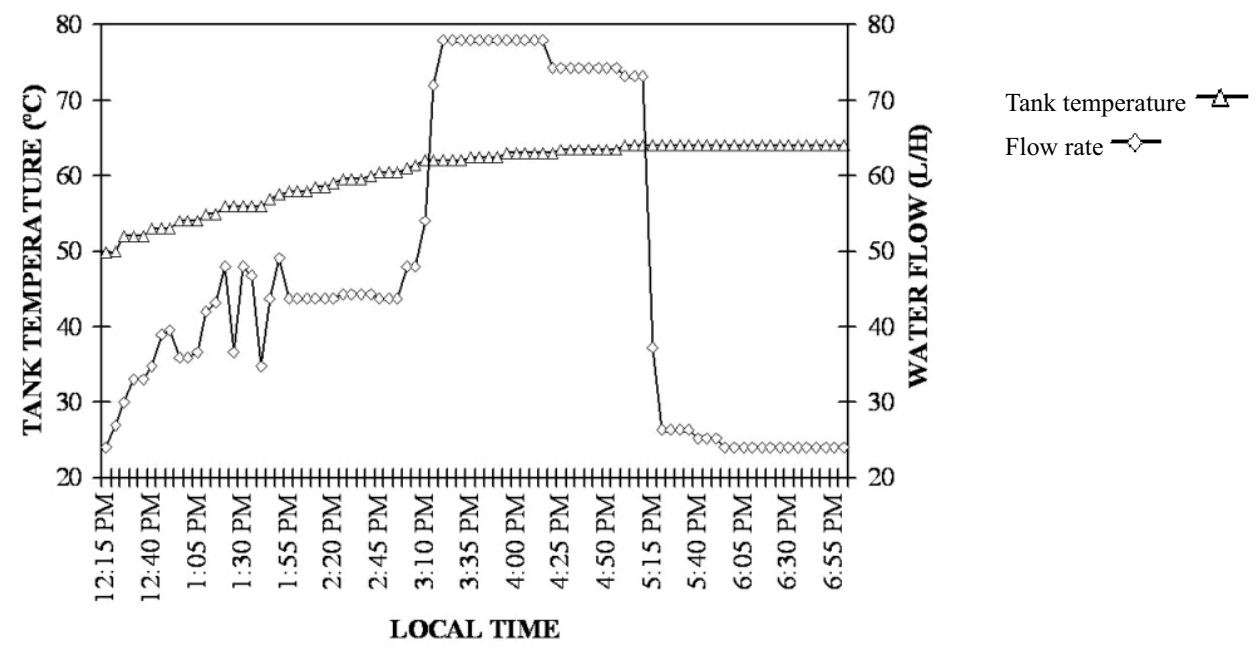

Figure 9. Water temperature inside the thermotank and water flow for May 10, 2006.

Local solar noon occurred at 13:35 PM 
DOI: http://dx.doi.org/10.22201/fi.25940732e.2009.10n3.025

A Flat Solar Collector Built from Galvanized Steel Plate, Working by Thermosyphonic Flow, Optimized for Mexican Conditions

Table 2. Instantaneous efficiency values for the collector, calculated for different tilt angles and radiation intensities

\begin{tabular}{ccccccc}
\hline Til & 500 & 600 & 700 & 800 & 900 & 1000 \\
\hline angle & $\mathrm{W} / \mathrm{m}^{2}$ & $\mathrm{~W} / \mathrm{m}^{2}$ & $\mathrm{~W} / \mathrm{m}^{2}$ & $\mathrm{~W} / \mathrm{m}^{2}$ & $\mathrm{~W} / \mathrm{m}^{2}$ & $\mathrm{~W} / \mathrm{m}^{2}$ \\
& $\eta_{i}(\%)$ & $\eta_{i}(\%)$ & $\eta_{i}(\%)$ & $\eta_{i}(\%)$ & $\left.\eta_{i} \%\right)$ & $\eta_{i}(\%)$ \\
$5^{\circ}$ & 34.4 & 42.6 & 48.5 & 52.9 & 56.3 & 59.0 \\
$10^{\circ}$ & 34.5 & 42.6 & 48.5 & 52.9 & 56.3 & 59.0 \\
$15^{\circ}$ & 34.5 & 42.7 & 48.5 & 52.9 & 56.3 & 59.0 \\
$20^{\circ}$ & 34.55 & 42.7 & 48.5 & 52.9 & 56.3 & 59.1 \\
$25^{\circ}$ & 34.6 & 42.7 & 48.6 & 53.0 & 56.4 & 59.1 \\
$30^{\circ}$ & 34.6 & 42.8 & 48.6 & 53.0 & 56.4 & 59.1 \\
$35^{\circ}$ & 34.7 & 42.8 & 48.7 & 52.0 & 56.4 & 59.2 \\
$40^{\circ}$ & 34.8 & 43.0 & 48.7 & 53.1 & 56.5 & 59.2 \\
$45^{\circ}$ & 34.9 & 43.0 & 48.8 & 53.2 & 56.5 & 59.2 \\
$50^{\circ}$ & 35.0 & 43.1 & 48.9 & 53.2 & 56.6 & 59.3 \\
$55^{\circ}$ & 35.1 & 43.2 & 49.0 & 53.3 & 56.7 & 59.4 \\
$60^{\circ}$ & 35.3 & 43.3 & 49.1 & 53.4 & 56.8 & 59.4 \\
\hline
\end{tabular}

were treated exclusively as direct radiation. The results are summarized in table 2.

The $\eta_{i}$ values calculated here for intermediate irradiation values (600 to $800 \mathrm{Watts} / \mathrm{m}^{2}$ ) are comparable to the thermal efficiency values (37\% to $52 \%$ ) experimentally determined by Shitzer et al. (1979) for solar domestic water heaters of the plate-and-tube-array type during the hours of highest insolation in Israeli mid-summer. The table shows that the tilt of the collecting plate has no large effect on the useful heat transferred to the fluid, as the overall variation in $\eta_{\mathrm{i}}$ over a $55^{\circ} \mathrm{C}$ change in tilt angle is only a few percent.

These theoretical results were compared to values determined experimentally at different times during a given day, November 4, 2007. To this end, the direct solar radiation was measured continually by pyrheliometer, while the global radiation incident on an horizontal surface was piranometrically monitored in the same location. The direct radiation incident on the collector surface was calculated through time from the pyrheliometrically measured values, considering the hour angle $(\omega)$, tilt angle $(\beta)$ and orientation $(\gamma)$ of the collector plate, and earth declination for the day of the year $(\delta)$, according to Tiwari (2002c). The direct radiation was similarly recalculated to give the direct component of the radiation incident on an horizontal surface through time. The diffuse contribution of radiation onto the horizontal surface was then computed by difference. Finally, the diffuse radiation incident on the collector plate was calculated from the diffuse radiation incident on an horizontal surface, using the equation given by Tabor (1978):

$$
f=\frac{1+\cos \theta}{2}
$$

where $f$ is the fraction of hemispherical sky seen by the collector at tilt angle $\theta$. Here we disregard any possible foreground albedo. Figure 10 shows, for the main sunshine period of this day, the value of the direct and the diffuse radiation incident on the collector plate, as well as the sum of the two.

The thermal efficiency at the different times was then calculated according to the following equation:

$$
\eta_{i}=\frac{\dot{m} C_{p}\left(T_{\text {exit }}-T_{\text {entrance }}\right)}{A I(t)}
$$

where the mass flow of the water, , was determined by flowmeter during the time under consideration, and 
$\mathrm{I}(\mathrm{t})$ is the global irradiance on the collector plate during this period, calculated as described above. The thermal efficiencies determined in this manner are plotted in figure 11 . The average thermal efficiency for the time between 10 AM and 4 PM is $59 \%$.

\section{Water analysis}

To test whether the contact of the hot water with the galvanized surface may have resulted in reduced water quality, a sample of the tank content was evaluated in an industrial test laboratory according to the appropriate
Mexican standard tests. The results are shown in table 3. As seen from this table, the quality of the hot water was good.

Test of the inside tank surface

After 1.5 years of daily use of the system, a small circle was cut out of the upper part of the tank, and the inside surface examined visually and by microscopy. Simple inspection showed the presence of a thin whitish layer, a fraction of a millimeter thick, locally formed as small spheres.

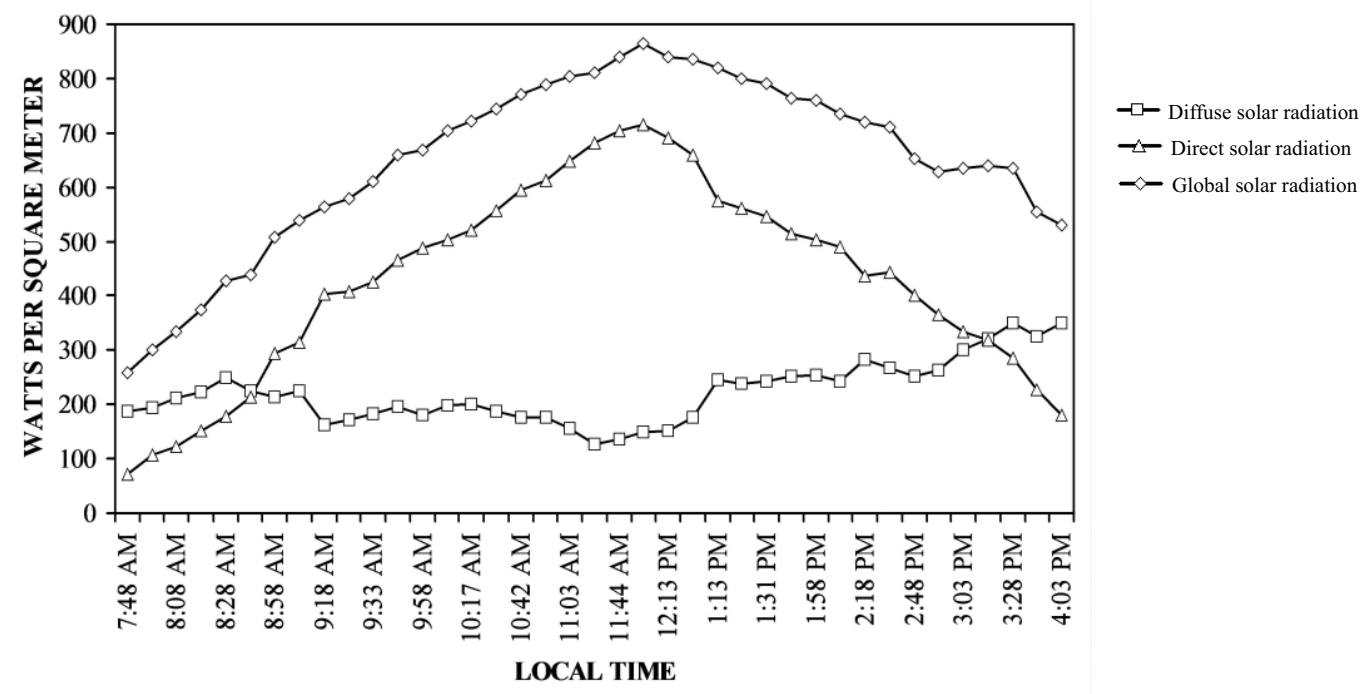

Figure 10. Direct, diffuse and global radiation on the collecting plate measured for November 4, 2007

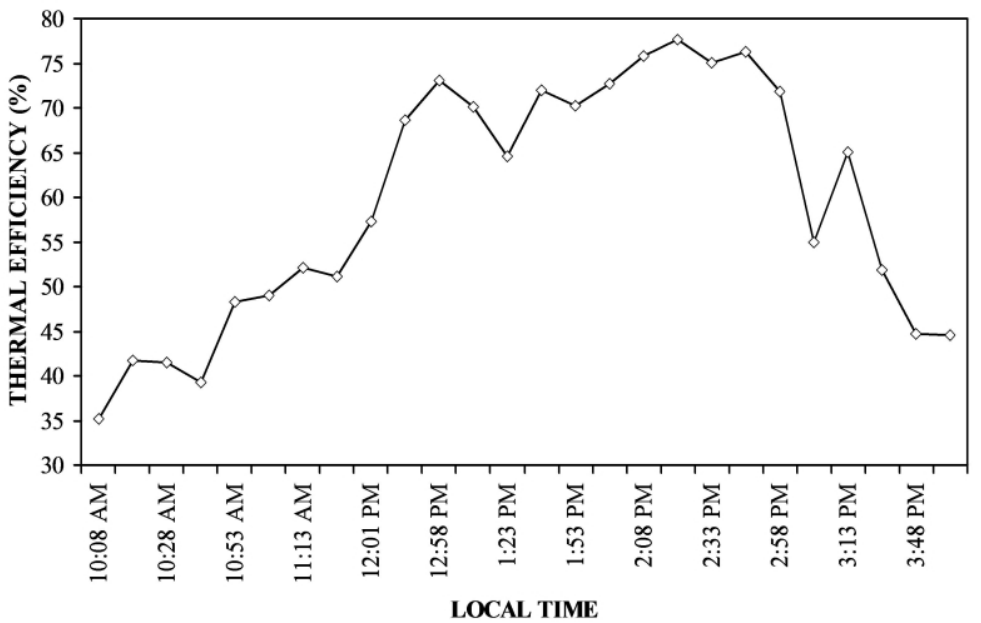

Figure 11. Instantaneous thermal efficiencies determined on November 4, 2007 
DOI: http://dx.doi.org/10.22201/fi.25940732e.2009.10n3.025

A Flat Solar Collector Built from Galvanized Steel Plate, Working by Thermosyphonic Flow, Optimized for Mexican Conditions

Table 3. Results of water testing

\begin{tabular}{cccc}
\hline Parameter & Result & Permissible limit & Mexican norm \\
\hline Color & $<5$ Pt-Co units & 20 Pt-Co units & NMX-AA-045-SCFI-2001 \\
Odor & Acceptable & Acceptable & NOM-201-SSA1-2002 \\
Taste & Acceptable & Acceptable & NOM-201-SSA1-2002 \\
Turbidity & $<5$ units & 5 units & NMX-AA-038-SCFI-2001 \\
Alcalinity & $121.5 \mathrm{mg} / \mathrm{L}$ & None stated & NMX-AA-036-SCFI-2001 \\
Total hardness & $51.7 \mathrm{mg} / \mathrm{L}$ & $500 \mathrm{mg} / \mathrm{L}$ & NMX-AA-072-SCFI-2001 \\
Total coliforms & $<2 \mathrm{NMP} / 100 \mathrm{~mL}$ & None detected & NOM-112-SSA1-1994 \\
Fecal coliforms & $<2 \mathrm{NMP} / 100 \mathrm{~mL}$ & None detected & NOM-112-SSA1-1994 \\
\hline
\end{tabular}

Figure 12. Microscopic image of the deposit on the inside surface of the thermotank. The scale represents one millimeter

These are clearly visible in the microscope image shown in figure 12. This result indicates that formation of deposits in the thermotank proceeds at a very slow rate.

\section{Discussion and analysis}

The performance of the flat solar collector proposed in the present work was evaluated experimentally, and it was found that for the month of February 2006, under usually cloudless skies, the maximum water temperatures in the tank achieved daily averaged $64.4^{\circ} \mathrm{C}$. The temperatures measured daily at 7:00 AM averaged $59.2^{\circ} \mathrm{C}$, implying an average reduction in tank water temperature of $5.2^{\circ} \mathrm{C}$ between afternoon and next sunrise. The theoretically calculated water temperature was $4.0^{\circ} \mathrm{C}$ lower than the average experimental temperature. The temperature calculated for the glass cover is $1^{\circ} \mathrm{C}$ higher than the average temperature determined experimentally. The calculated surface temperature of the channeled sheet was $32.6^{\circ} \mathrm{C}$ higher than the experimentally determined average during thermosyphonic operation, which is not surprising as the calculations did not take into account the cooling effect of the water which flows through the absorbing plate.

High thermal efficiencies are achieved, even with the passive mode of water movement, a result of the high radiation intensity and warm air conditions in Mexico, in conjunction with the unimpeded water flow through the wide channels. This is in contrast to the results of Lee and Sharma (2007), who in the more adverse climate conditions of Korea and with flat solar collectors using narrow risers found distinctly lower thermal efficiencies with the active and especially with the passive flow system. 
DOI: http://dx.doi.org/10.22201/fi.25940732e.2009.10n3.025

Á. Marroquín de Jesús, J.M. Olivares-Ramírez, G.A. Ramos-López and R.C. Pless

The high flow rates achieved in thermosyphonic operation with our prototype are due not only to the facile linear flow in the vertical channels, but even more importantly due to the avoidance of tight tee junctions, significantly reducing junction pressure loss (Kikas, 1995).

As discussed by Grossman et al. (1977) in their consideration of a parallel-plate absorber (a configuration approximated in our design), the separation between the plates affects the overall efficiency in opposite ways: the smaller this separation, the better the collection efficiency, but too small a separation between the plates could lead to lower throughput rates and also, eventually, to clogging by scale formation. Here we show that with the dimensions dictated by our choice of construction materials, i.e. channels of $1 \mathrm{~cm}$ depth, high flow rates are achieved in thermosyphonic operation, while simultaneously maintaining high thermal transfer, with single-pass temperature increases of $13^{\circ} \mathrm{C}$ to $18^{\circ} \mathrm{C}$ at high insolation.

In this work less emphasis was placed on maximizing thermal efficiency than on robustness of design and low-cost manufacturability. Nonetheless, the prevalent local climatic conditions make for low thermal losses, which results in an acceptable thermal efficiency; this in conjunction with the high irradiance levels, provides for a high thermal output. This, in turn, allowed reducing the dimensions of the prototype, compared to other single-family models, which redounds in a reduction in the cost of materials and an easier installation on the sometimes crowded rooftops of small residential units.

\section{Conclusions}

We have presented a mathematical model to calculate the temperatures at the solar collector, and these are correlated to easily measured parameters. The analysis was performed in steady state, and the results provided by the mathematical model are similar to those obtained experimentally. The mathematical approach presented here allows evaluation of different types of flat solar collectors. The design achieves a reduction in capture area of $20 \%$ with respect to the standard collector with its area of almost two square meters; this represents a significant reduction in the size of the collector. The collector presented here allows heating the same amount of water which is heated with the standard two-square-meter collectors in the market.

The geometry of the collector offers a high contact area between the fluid and the collecting surface exposed to the sun. The simple design of the system makes for robustness in its performance, as thermal transfer between the heated metal surface of the channels and the water flowing within is straightforward.

Another important factor is the cost reduction made possible by the simplicity of the design, which makes acquisition of this water-heating device for home use more realistic. The materials used in the construction of this collector are easily obtained and durable. An estimate of the cost of production of this hot-water system, already installed, is 3,500 Mexican pesos, including the thermotank and all external tubing connections. The low cost is due to the simplicity of the design, which reduces the welding effort compared to systems with tubular risers, the relatively low labor cost in Mexico, and the low price of galvanized channeled sheet, which is produced on a large scale. A reasonable selling price would be 7,000 pesos for the entire unit. By our own year-round experience with a fourmember family, installing this system allows a reduction of 460 liters/year in the use of liquid-propane gas for hot bath water, i.e. a cost reduction of about 3,000 pesos/year at current prices. With this, the family budget outlay involved in the purchase of such a system would be amortized in under 2.4 years. Thus, payback times are much shorter than for technically more sophisticated systems in colder climes, even when these latter ones enjoy major government subsidies (Pedersen, 1993). The financial benefit will accrue over many years, as simple solar collectors remain serviceable for 15 years or more, performing at acceptable levels of thermal efficiency (Rudnick, 1986). Likely future price increases for gas will make this option even more attractive. In terms of environmental benefit one can calculate that during this lifetime of 15 years, the use of a water heater of this type would redound in a reduction of carbon dioxide emissions of over 10 tons (RETScreen International, 2005).

While we have optimized our model for the specific situation of central Mexico, it is likely that it could also be used to advantage in other tropical and subtropical regions of the world, where conditions of high insolation obtain and where considerations of price may be decisive for the acquisition of a solar collector.

\section{Nomenclature}

A Upper surface area of the collector plate

$E_{b 1}$ Emissive power of the channeled sheet

$E_{b 2} \quad$ Emissive power of the glass cover

$E_{b 3}$ Emissive power of the ambient air

$C_{p}$ Heat capacity of water 
DOI: http://dx.doi.org/10.22201/fi.25940732e.2009.10n3.025

A Flat Solar Collector Built from Galvanized Steel Plate, Working by Thermosyphonic Flow, Optimized for Mexican Conditions

h Thermal convectivity constant for water

$h_{3}$ Thermal convectivity constant for the ambient air

$I(t)$ Intensity of incident radiation at time $\mathrm{t}$

$k_{e}$ Thermal conductivity constant of the channeled sheet

$k_{1,2}$ Thermal conductivity constant for the air contained in the chamber

$\dot{m}$ Mass flow rate

$\dot{q}_{a b} \quad$ Flux density for the solar energy absorbed by the collector surface

$\left.\frac{\dot{q}}{A}\right|_{\text {Rad }}$ Radiative energy flow per unit area

$\frac{\dot{q}}{A} \quad$ Energy flow per unit area for the global system

$\dot{Q}_{u} \quad$ Useful energy output per unit time for the collector

$T_{a}=T_{3}$ Ambient air temperature

$T_{\text {entrance }}$ Water temperature at entrance to collector

$T_{\text {exit }}$ Water temperature at exit from collector

$T_{p}=T_{1}$ Mean absorber plate outside surface temperature

$T_{2} \quad$ Outer surface temperature of the glass cover

$T_{1}=T_{p}$ Mean absorber plate outside surface temperature

$T_{3}=T_{a}$ Ambient air temperature

$T_{5}$ Water temperature

$U_{L} \quad$ Overall heat loss coefficient

$\alpha_{0} \quad$ Plate absorptivity

$\beta \quad$ Tilt angle

$\gamma$ Surface orientation of the collector plate

$\delta$ Declination

$\Delta x$ Thickness of the channeled sheet

$\Delta x_{1,2}$ Distance from the absorbing sheet to the glass cover

$\varepsilon_{2} \quad$ Emissivity of the cover glass

$\eta_{i} \quad$ Instantaneous efficiency

$\Theta \quad$ Tilt angle

$\tau_{0} \quad$ Transmissivity of the glass cover

$\omega$ Hour angle

\section{Acknowledgements}

Financial support from the Fondo Mixto CONACYT Gobierno del Estado de Querétaro (Project ORO-2004-C01-27) is gratefully acknowledged. We also thank the State Water Commission (Comisión Estatal de Aguas del Estado de Querétaro) for making available the Davis Vantage Pro2 weather station.

\section{References}

Almanza R. Mapas de irradiación solar en la República Mexicana. Capítulo 1. On: Ingeniería de la Energía Solar II, Almanza R., Ed. Mexico City. Universidad Nacional Autónoma de México. 2003.

Clark P.C. Heat Transfer Panel and Method. U.S. Patent 4,473,066. 1984.

Duffie J.A., Beckman W.A. Solar Engineering of Thermal Processes. Second Edition. New York. Wiley. 1991. P. 210.

Dunn D.C., Tweed J.C. Solar Heater Unit. U.S. Patent 4,286,583. 1981.

Fischer S., Heidemann W., Müller-Steinhagen H., Perers B., Bergquist P., Hellström B. Collector Test Method Under Quasi-Dynamic Conditions According to the European Standard EN 12975-2. Solar Energy, 76:117-123. 2004.

Grossman G., Shitzer A., Zvirin Y. Heat Transfer Analysis of a Flat-Plate Solar Energy Collector. Solar Energy, 19:493502. 1977.

Holman J.P. Heat Transfer. Seventh Edition. New York. Mc Graw-Hill. 2001. Pp. 474-475.

Kikas N.P. Laminar Flow Distribution in Solar Systems. Solar Energy, 54:209-217. 1995.

Lee D.W, Sharma A. Thermal Performances of the Active and Passive Water Heating Systems Based on an Annual Operation. Solar Energy, 81:207-215. 2007.

Pedersen P.V. System Design Optimization for Large Building Integrated Solar Heating Systems for Domestic Hot Water. Solar Energy, 50:267-273. 1993.

RETScreen International. Clean Energy Project Analysis Software. Canada, 2005.

Rudnick A., Kaplan Y., Kudish A.I., Wolf D. A Study of Solar Collector Aging, Installation and Materials Problems. Solar Energy, 36:227-240. 1986.

Shitzer A., Kalmanoviz D., Zvirin Y., Grossman, G. Experiments with a Flat Plate Solar Water Heating System in Thermosyphonic Flow. Solar Energy, 22:27-35. 1979.

Tabor H. Testing of Solar Collectors. Solar Energy, 20:293-303. 1978.

Tiwari G.N. Solar Energy: Fundamentals, Design, Modeling and Applications. Alpha Science International. 2002a. P. 121. 
DOI: http://dx.doi.org/10.22201/fi.25940732e.2009.10n3.025

C.A. Escalante-Sandoval

regional at-site estimates of low-flow by using the station-year method (Cunnane, 1988). For this purpose, there are two gauging stations upstream of the station La Parota, called El Puente and Agua Salada, whose 70 flows were used to obtain a regional at-site quantile of the ${ }_{7} \mathrm{O}_{10}$ flows. The best fit was achieved through the use of the EV1MIX distribution, and the low flow ${ }_{7} \mathrm{O}_{10}$ $=11.85 \mathrm{~m}^{3} / \mathrm{s}$ would be the minimum value of the discharge to maintain the conditions of water quality downstream of the dam.

\section{Conclusions}

In both applications the proposed mixed distributions behave very well. In the first case results shown that there exists a reduction in the standard error of fit when estimating the quantiles with mixed distributions (EV1MIX, 30\% of cases and the TCEVMIN, 13\%) in comparison with the GEV (49\%), W3 (8\%) and EV1 $(0 \%)$ distributions. In the second one, the best hydrological design event was obtained by using the EV1MIX distribution along with a regional technique $\left.{ }_{7} \mathrm{Q}_{10}=11.85 \mathrm{~m}^{3} / \mathrm{s}\right)$. It is very important to mention that it was not the intention of this paper to propose the final ecological flow for the hydroelectric project, but only to show the hydrological application of mixed distribution in studies of water quality.

Results indicate that mixed distributions can be considered as an additional tool when performing low-flow frequency analysis.

\section{References}

Al-Mashidani G., Lal B.B., Quadri I. Drought Flow Analysis of River Tigris in Baghdad. Hydrological Science Journal. 25(4):453-459. 1980.

Chow V. T. Handbook of Applied Hydrology. Mc. Graw-Hill. 1964.
Cunnane C. Methods and Merits of Regional Flood Frequency Analysis. Journal of Hydrology, 100:269-290. 1988.

EPA. Environmental Protection Agency. July, 2006 [on line]. Available on: www.epa.gov

Gumbel E.J. Statistics of Extremes. Columbia University Press. New York. USA. 1958.

Kite G.W. Frequency and Risk Analyses in Hydrology. Water Resources Publications. USA. 1988. 257 p.

Kroll Ch., Vogel R. Probability Distribution of Low Stream Flow Series in the United States. Journal of Hydrologic Engineering, 7(2):137-146. 2002.

Kuester J.L., Mize J.H. Optimization Techniques with FORTRAN. McGraw-Hill Book Co. New York, 1973. Pp. 386-398.

Mood A. , Graybill F., Boes D. Introduction to the Theory of Sstatistics. McGraw-Hill. 1974.

Onoz B., Bayazit M. GEV-PWM Model for Distribution of Minimum Flows. Journal of Hydrologic Engineering, 4(3):289-292. 1999.

Pearson C.P. Regional Frequency Analysis of Low Flows in New Zealand Rivers. Journal of Hydrology, 30(2): 53-64. 1995.

Pyrce R.S. Hydrological Low Flows Indices and their Uses. WSC Report No. 04-2004. Watershed Science Centre. Peterborough. Ontario. 2004. 33 p.

Raynal J.A. Computation of Probability Weighted Moments Estimators for the Parameters of the General Extreme Value Distribution (Maxima and Minima). Hydrological Science and Technology, 3(1-4):47-52. 1987.

Rossi F., Fiorentino M., Versace P. Two Component Extreme Value Distribution for Flood Frequency Analysis. Water Resources Research, 20(7):847-856. 1984.

Smakhtin V. Low Flow Hydrology: a Review. Journal of Hydrology, 240(3-4):147-186. 2001

Waylen P.R., Woo M. Annual Low Flows Generated by Mixed Processes. Hydrological Science Journal, 32(3):371-383. 1987.

\section{About author}

Carlos Agustín Escalante-Sandoval. Civil Engineer (BUAP, 1985), M in S with major in Water Resources (UNAM, 1988), Ph D with major in Hydraulics (UNAM, 1991). He was Head of Hydraulics Department up to 2007 and currently Head of Civil Engineering Graduated Department, both in the Faculty of Engineering at UNAM. He has been granted some academic and scientific prizes such as the Gabino Barreda Medal in 1991 by UNAM and the Prize for Research "Enzo Levi" in 2000 by the Mexican Association of Hydraulics. He has been member of the American Society of Civil Engineers, the American Water Resources Association, The American Geophysical Union, the New York Academy of Sciences, the Mexican Academy of Sciences, the Mexican Academy of Engineering and the National System of Researches. 
DOI: http://dx.doi.org/10.22201/fi.25940732e.2009.10n3.025

Á. Marroquín de Jesús, J.M. Olivares-Ramírez, G.A. Ramos-López and R.C. Pless

Tiwari G.N. Solar Energy: Fundamentals, Design, Modeling and Applications. Alpha Science International. 2002b. Pp. 114-115.

Tiwari G.N. Solar Energy: Fundamentals, Design, Modeling and Applications. Alpha Science International. 2002c. Pp. 17-19.
Wang X.A., Wu L.G. Analysis and Performance of Flat-Plate Solar Collector Arrays. Solar Energy, 45:71-78. 1990.

\section{About the authors}

Ángel Marroquín de Jesús. He obtained his Bachelor's degree in Electrical Engineering from the Oaxaca Technological Institute (in Mexico), and his Master of Science degree from the Morelia Technological Institute, in the Graduate Program in Electrical Engineering. His Doctoral degree is from the National Polytechnic Institute, conferred by the Graduate Program in Advanced Technologies, CICATA-IPN, Querétaro Section. At present he is a Professor at the Technological University of San Juan del Río. During the past 7 years he has taken part in various projects and studies dealing with activities in the commercial sector, generally in the areas of industrial maintenance, energy savings, and assurance of energy quality. He has mathematically modelled, designed, and built appliances which work based on solar energy (cookers, heaters, ovens, and concentrators). In the past 3 years he has carried out extensive solar radiation measurements using instruments such as pyrheliometers and piranometers. He has published over 5 articles in international meetings and over 30 articles in national meetings.

Juan Manuel Olivares-Ramirez. He obtained his Bachelor's degree in Mechanical Engineering from the Morelia Technological Institute (in Mexico), and his Master's degree in Materials Science from the same institution. His Doctoral degree is from the National Polytechnic Institute, conferred by the Graduate Program in Advanced Technologies, CICATA-IPN, Querétaro Section. At present he is an Associate Professor at the Technological University in San Juan del Río, in the state of Querétaro. He has headed up various collaborative projects with the commercial sector, and has directed 5 Bachelor's theses and over 50 Technician's theses at the Technological University of San Juan del Río. He has published over 15 articles in national meetings and 5 in international meetings, as well as three articles in strictly refereed journals. His research work has centred on methods of hydrogen production, refrigeration systems, and solar cookers and heaters.

Gonzalo A. Ramos-López. He obtained his Doctorate in Natural Sciences from the University of Bayreuth, Federal Republic of Germany, based on his research work performed at the Max-Planck Institute for Plasma Physics. On his return to Mexico he became Head of the Radiometry Division of the National Metrology Centre. He is a member of the National System of Researchers, level I. At present, he is Full Professor at the Centre for Research in Applied Science and Advanced Technology of the National Technological Institute, Querétaro Section. His main research lines are Alternative Energies (solar thermal energy, nuclear fusion energy) and Materials Science (magnetic materials, ceramic materials for extreme applications, and biomaterials).

Reynaldo C. Pless. He took his Doctoral degree in Chemistry from Northwestern University, Evanston, Illinois, U.S.A. After Postdoctoral work at the Johns Hopkins University, Baltimore, Maryland, and at the Polish Academy of Sciences in Warsaw, he joined the Ohio State University in Columbus, Ohio, as Chemistry Professor . He later moved to Life Technologies, Inc., in the state of Maryland, to head the Product Development Group. In 1997, he joined the Centre for Applied Science and Advanced Technologies of the National Technological Institute (CICATA-IPN), initially in Mexico City and later in Querétaro, where he is working as Full Professor and Researcher, on the design of home appliances which work on the basis of alternative energies, on chemical and physical changes in the maize kernel during alkaline cooking, and on the chemistry of nucleic acids. At present, he is a member of the National System of Researchers, level II. 